\title{
Soil organic carbon in the rocky desert of northern Negev (Israel)
}

\author{
Ulrike Hoffmann • Aaron Yair • Harald Hikel • \\ Nikolaus J. Kuhn
}

Received: 24 July 2011 / Accepted: 2 March 2012 /Published online: 5 April 2012

(C) Springer-Verlag 2012

\begin{abstract}
Purpose So far, the soil organic carbon (SOC) literature is dominated by studies in the humid environments with huge stocks of vulnerable carbon. Limited attention has been given to dryland ecosystems despite being often considered to be highly sensitive to environmental change. Thus, there is insufficient research about the spatial patterns of SOC stocks and the interaction between soil depth, ecohydrology, geomorphic processes, and SOC stocks. This study aimed at identifying the relationship between surface characteristics, vegetation coverage, SOC, and SOC stocks in the arid northern Negev in Israel.

Materials and methods The study site Sede Boker is ideally suited because of well-researched but variable ecohydrology. For this purpose, we sampled five slope sections with different ecohydrologic characteristics (e.g., soil and vegetation) and calculate SOC stocks. To identify controlling factors of SOC stocks on rocky desert slopes, we compared soil properties, vegetation coverage, SOC concentration, and stocks between the five ecohydrologic units.

Results and discussion The results show that in Sede Boker, rocky desert slopes represent a significant SOC pool with a mean SOC stock of $0.58 \mathrm{~kg} \mathrm{C} \mathrm{m}^{-2}$ averaged over the entire
\end{abstract}

Responsible editor: Zucong Cai

U. Hoffmann $(\bowtie) \cdot$ H. Hikel $\cdot$ N. J. Kuhn

Department of Environmental Science,

Physical Geography and Environmental Change,

University of Basel,

Klingelbergstrasse 27,

4056 Basel, Switzerland

e-mail: ulrike.hoffmann@unibas.ch

\section{A. Yair}

Department of Geography, Hebrew University of Jerusalem,

Mount Scopus,

Jerusalem 91905, Israel study area. The spatial variability of the soil coverage represents a strong control on SOC stocks, which varies between zero in uncovered areas and $1.54 \mathrm{~kg} \mathrm{C} \mathrm{m}^{-2}$ on average in the soil-covered areas. Aspect-driven changes of solar radiation and thus of water availability are the dominant control of vegetation coverage and SOC stock in the study area.

Conclusions The data indicate that dryland soils contain a significant amount of SOC. The SOC varies between the ecohydrologic units, which reflect (1) aspect-driven differences, (2) microscale topography, (3) soil formation, and (4) vegetation coverage, which are of greatest importance for estimating SOC stocks in drylands.

Keywords Drylands · Ecohydrology · Rocky deserts . SOC stock · Soil organic carbon · Topography

\section{Introduction}

1.1 Soil organic carbon and the global carbon cycle

The global soil system is the largest terrestrial reservoir of organic carbon, which stores approximately 2,400 $\mathrm{Pg}$ $\left(\mathrm{Pg}=10^{15} \mathrm{~g}\right)$ of soil organic carbon (SOC) in the top $2 \mathrm{~m}$ (Amundson 2001; Kirschbaum 2000). Soil and climate systems are closely coupled through the exchange of $\mathrm{C}$ between the atmosphere, biosphere, and pedosphere (Berhe et al. 2008). Therefore, there has been increasing international interest in the ability of soils to affect atmospheric concentrations of carbon dioxide $\left(\mathrm{CO}_{2}\right)$ (Houghton 2007; Mishra et al. 2009; Sarmiento and Gruber 2002; Schlesinger 1977, 1990; Wigley and Schimel 2005). The risk of global warming and the potential to use soils as a carbon sink in the context of the Kyoto Protocol have increased the attention of the scientific 
community to SOC stocks and fluxes in terrestrial ecosystems, especially in regions sensitive to climatic change (Branchu et al. 1993; IPCC 2007; Mishra et al. 2009; Smith and Heath 2002). However, the size and dynamics of the global SOC pool are still not well known (IPCC 2007; Quinton et al. 2010; Seip 2001). Precise measurements and estimates of the spatial distribution of SOC stocks are necessary to quantify the SOC sink or source capacity of soils in changing environments. The spatial variation of SOC is significantly influenced by environmental factors such as climate, topography, soil and bedrock materials, vegetation, disturbance, and surface processes due to human activity (Tan et al. 2004).

\subsection{Carbon stocks in drylands}

Even though drylands occupy $47.2 \%$ of the earth's land surface, their importance in the global carbon cycle received limited attention (Asner et al. 2003; Schimel 2010). Global dryland soils contain $15.5 \%$ of the world's total SOC to $1 \mathrm{~m}$ depth (IPCC 2007; Lal 2003; Lal et al. 2001; Schimel et al. 2000). This is about 40 times more than what was added during the 1990s into the atmosphere through anthropogenic activities, estimated at $6.3 \mathrm{Pg} \mathrm{C}_{\text {year }}{ }^{-1}$ (IPCC 2007; Lal 2003; Lal et al. 2001; Schimel et al. 1994, 2000). Dryland ecosystems are often regarded as "hot spots" of climate change, with large, rapid, and variable responses to even the smallest changes of climate conditions (Farage et al. 2003; Lal 2003; Yair 1990). Furthermore, dryland soils are prone to degradation and desertification due to human activities. Consequently, the majority of degraded dryland soils can be considered as far from SOC saturation, suggesting a high potential of SOC uptake (Farage et al. 2003; Lal 2003). Additionally, recent results (Rotenberg and Yakir 2010) show that dryland forests in Israel take up carbon at rates similar to forests in more humid continental Europe. Based on these results, they suggest that $1 \mathrm{Pg}$ out of $3.2 \mathrm{Pg}$ generating the annual increase in atmospheric concentration of $\mathrm{CO}_{2}$ can be sequestered by reforestation of dryland soils. In contrast to soils from humid regions, dryland soil areas are less likely to lose SOC because the lack of water limits SOC mineralization and therefore the flux of SOC into the atmosphere. Consequently, the residence time of SOC in desert soils can be much longer than in soils of humid regions (Glenn et al. 1993), and the ratio of the soil to living biomass SOC pool might be greater in drylands than in tropical forests (Farage et al. 2003; Lal 2009; Lal et al. 2001).

1.3 SOC-stock calculation and links to soil-forming factors

SOC stocks $\left(\mathrm{kg} \mathrm{C} \mathrm{m}^{-2}\right)$ are generally calculated based on the

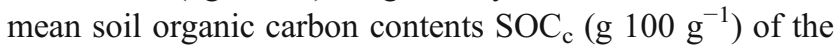
fine soil fraction $(<2 \mathrm{~mm})$, the mean bulk density BD (in grams per cubic centimeter), the mean mass ratio of coarse soil fragments $(>2 \mathrm{~mm}) \mathrm{CF}_{\mathrm{i}}\left(\mathrm{g} 100 \mathrm{~g}^{-1}\right)$, and the soil thickness $d_{\text {soil }}$ (centimeters):

$\mathrm{SOC}_{\text {stock }}=0.1 \times d_{\text {soil }} \times \mathrm{BD} \times \mathrm{SOC}_{\mathrm{c}} \times(1-\mathrm{CF} / 100)$

In humid environments, which are characterized by strong agricultural activity, human-controlled land cover generally exerts a strong variability on SOC concentration that in turn dominates the spatial variability of SOC stock (Goidts and van Wesemael 2007; Grieve 2001; Lal 2005; Leifeld et al. 2005; van Wesemael et al. 2010). In arid environments, however, the link between SOC stocks and soil-forming factors (such as climate, vegetation, and bedrock material) is much more complex than in humid agricultural landscapes. Significant diurnal temperature changes and the water deficit result in high physical and low chemical weathering rates (FAO 2004). The strong disintegration of rocks and the low chemical transformation therefore suggest a strong control of properties of the parent material (e.g., given by soil thickness, $\mathrm{BD}$, and $\mathrm{CF}$ in Eq. (1)) on SOC stocks. Parent material in arid environments is often transported during severe soil erosion caused by extreme precipitation events (Yair 1990). Wash processes, however, are not continuous but disconnected, and sediment is generally transported only over short distances due to the disconnectivity of overland flows (Michaelides and Chappell 2009; Yair 1992). Thus soils, especially in arid environments, need to be "considered as mobile systems, which has major consequences for terrestrial biogeochemical cycles" (Quinton et al. 2010). Furthermore, arid environments lack a continuous vegetation coverage but are dominated by shrub vegetation that concentrates the biogeochemical activity in "islands of fertility" (Schlesinger and Pilmanis 1998; Schlesinger et al. 1996). Therefore, the shift from continuous grassland to patchy shrub vegetation with increasing aridity introduces a further element of complexity in the distribution of SOC stocks.

\subsection{Estimation of dryland SOC stocks}

Due to continuous runoff under humid conditions, SOC stocks are generally related to the surface morphology, which controls processes such as erosion and deposition and thus SOC fluxes and sequestration (Egli et al. 2009; Griffiths et al. 2009; Rosenbloom et al. 2006; Tan et al. 2004; Yoo et al. 2006). Topographic parameters, such as slope (Berhe et al. 2008; Tsui et al. 2004), curvature (Rosenbloom et al. 2006; Yoo et al. 2006), and relief position (Glatzel and Sommer 2005), have been shown to correlate with SOC stock under humid conditions. In contrast to humid environments with well-developed soils, arid environments with shallow soils are characterized by a lack of connectivity in runoff causing in turn an exceedingly high spatial variability of soil depth (Laity 2008; Parsons and Abrahams 2009; Yair 1990; 
Yair and Danin 1980). Since runoff exerts a strong control over water availability, soil formation, and soil erosion and deposition, simple relationships of topographic parameters (such as slope, curvature, and wetness index) and soil properties and SOC stocks are not expected in arid environments.

Vegetation needs to be considered as a major factor controlling SOC stocks in arid environments (FAO 2004; Zhou et al. 2011). First, strong variations of soil moisture availability cause a patchy vegetation distribution, which in turn may exert a strong control on carbon stocks (OlsvigWhittaker et al. 1983; Schlesinger et al. 1996). Second, in contrast to humid environments, which are characterized by high net primary production (NPP) and increased organic matter mineralization, dry environments have lower NPP, but also lower decomposition rates (Lal 2009; Schlesinger 1991). Third, while high temperatures favor high $\mathrm{CO}_{2}$ efflux, low decomposition rates (due to water deficit) limit vegetation-driven carbon sequestration in hot arid climates (Fang and Moncrieff 2001; Farage et al. 2003; Qi et al. 2002) and thus may limit the impact of vegetation on SOC stocks. Thus, the link between soil moisture, vegetation coverage, and soil properties to SOC stocks and their relative importance for the spatial patterns of SOC stock in arid environments are much less clear than under humid conditions.

The spatial variability of relevant soil properties (Eq. (1)) presents a major challenge to the establishment of SOC stocks in arid and semi-arid environments. Despite the apparent significance of the dryland SOC pool, systematic studies on the spatial variability and the effects of environmental factors (such as soil moisture and vegetation coverage) in rocky desert soils are still missing. Thus, there is a strong need to estimate SOC stocks in arid soils and to evaluate their importance under a changing climate (Rotenberg and Yakir 2010; Schimel 2010). This need provides the major motivation of our study, which aims (1) to determine SOC stocks in a range of ecohydrologically different slope environments, (2) to identify soil properties relevant for the SOC stocks in each ecohydrologic setting, and (3) to assess the effects of NPP (represented by vegetation coverage) on SOC stocks.

The study was conducted in the northern highlands of the Negev desert in Israel near the town of Sede Boker, which is ideally suited because of well-researched ecohydrology. The influence of surface properties and patches of rock and soil on ecohydrology and vegetation has been intensely investigated in this area (e.g., Evenari et al. 1980; OlsvigWhittaker et al. 1983; Yair 1990; Yair and Danin 1980). Based on this research, it was possible to determine SOC stocks in a range of ecohydrologically different slope environments and to identify soil properties relevant for SOC concentration and stock. The established link between vegetation coverage and water supply at Sede Boker also offers the opportunity to test the effects of ecohydrology on SOC, especially the balance between NPP (indicated by vegetation coverage) and SOC-stock development.

\section{Study site}

The Sede Boker research area is located in a second-order drainage basin (4.5 ha) about $40 \mathrm{~km}$ south of Beersheva $\left(30^{\circ}\right.$ $52^{\prime} \mathrm{N}, 34^{\circ} 48^{\prime}$ E) in the northern Negev Desert of Israel (Fig. 1). The elevation ranges between 485 and $535 \mathrm{~m}$ above sea level. The mean annual air temperature in Sede Boker is $20{ }^{\circ} \mathrm{C}$ (Dan et al. 1972), and mean monthly temperatures vary from $9{ }^{\circ} \mathrm{C}$ in January to $25^{\circ} \mathrm{C}$ in August. The average annual rainfall, observed during a 30-year period (Yair 1994), ranges from 34 to $167 \mathrm{~mm}$, with an average of $91 \mathrm{~mm}$ (Kuhn and Yair 2004). Rainfall is concentrated during the winter season between October and April. Potential evaporation rates are approximately 2,500 mm, generating an arid climate (Evenari et al. 1980; OlsvigWhittaker et al. 1983; Yair and Danin 1980).

The Upper Cretaceous bedrock stratigraphy is composed of three limestone formations that are the Netser, Shivta, and Drorim formation (Fig. 2). Based on Yair and Danin (1980), Olsvig-Whittaker et al. (1983), and Schreiber et al. (1995), the formations can be classified in four meso-scale surface structural units (Upper Netser, Lower Netser/Upper Shivta, Lower Shivta, colluvium above Drorim). The upper part of the slope is characterized by the Upper Netser formation with thinly bedded limestones and flint concretions. The lower part of the Netser and the Upper Shivta formation is a thinly bedded and densely fissured formation and could be considered as one structural unit according to OlsvigWhittaker et al. (1983). The Lower Shivta formation is a massive unit with a low density of deep cracks. The Drorim formation represents the lowest unit, which is densely jointed and covered with an extensive colluvial mantle (Yair and Shachak 1982) (see Fig. 2). These bedrock formations provide distinctive surface properties influencing hydrology, plant communities, and therefore potentially the spatial distribution of SOC concentration and SOC stock.

In situ chemical weathering of bedrock is of minor importance for soil formation. Most of the substrate is not derived from the local limestone, but composed of aeolian loess-like sediments, which were deposited since the early Quaternary (Bruins 1986; Reifenberg 1947; Yaalon and Dan 1974). Based on the World Reference Base for Soil Resources (IUSS Working Group WRB 2006), the soil is dominantly classified as a desert brown Lithosol (Arkin and Braun 1965; Dan et al. 1972) with patchy and thin soil cover. Generally, the study area is characterized by three soil bedding types: (1) soil patches, which are mainly located at the base of rock steps, (2) soil material filling crevices 


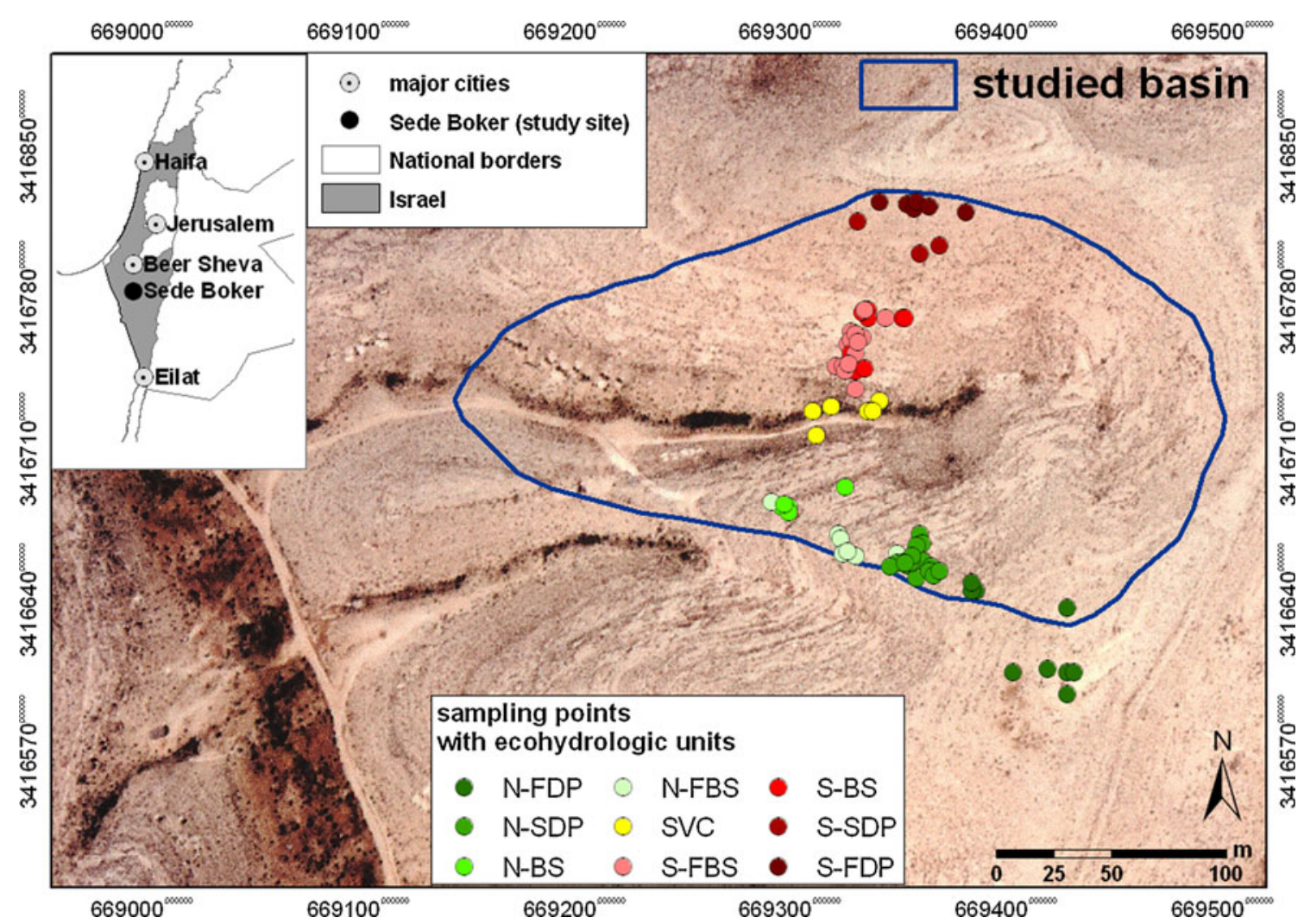

Fig. 1 Location of the study site and sampling points with respect to aspect and ecohydrologic units. $N$ and $S$ indicated northern and southern aspects, respectively. $F D P$ flat desert pavement, $S D P$ gently sloped desert pavement, $F B S$ stepped and fissured bedrock slope, $B S$ non-

fissured bedrock slope, $S V C$ slope and valley colluvium. Coordinates are given by projection system UTM longitude zone 36 , latitude zone R, ellipsoid WGS 84

and fissures generated by rock shattering, and (3) colluvial soil sheets on bedding planes of the near surface rock strata. The loessic substrate is high in sand and silt (85-95\%), while clay content varies between $14.5 \%$ in joints and

crevices and 7-10\% in soil patches covering bedding planes (Olsvig-Whittaker et al. 1983; Yair and Danin 1980). Due to the arid conditions, with low vegetation coverage and high wind speeds and surface runoff, the soil genesis is

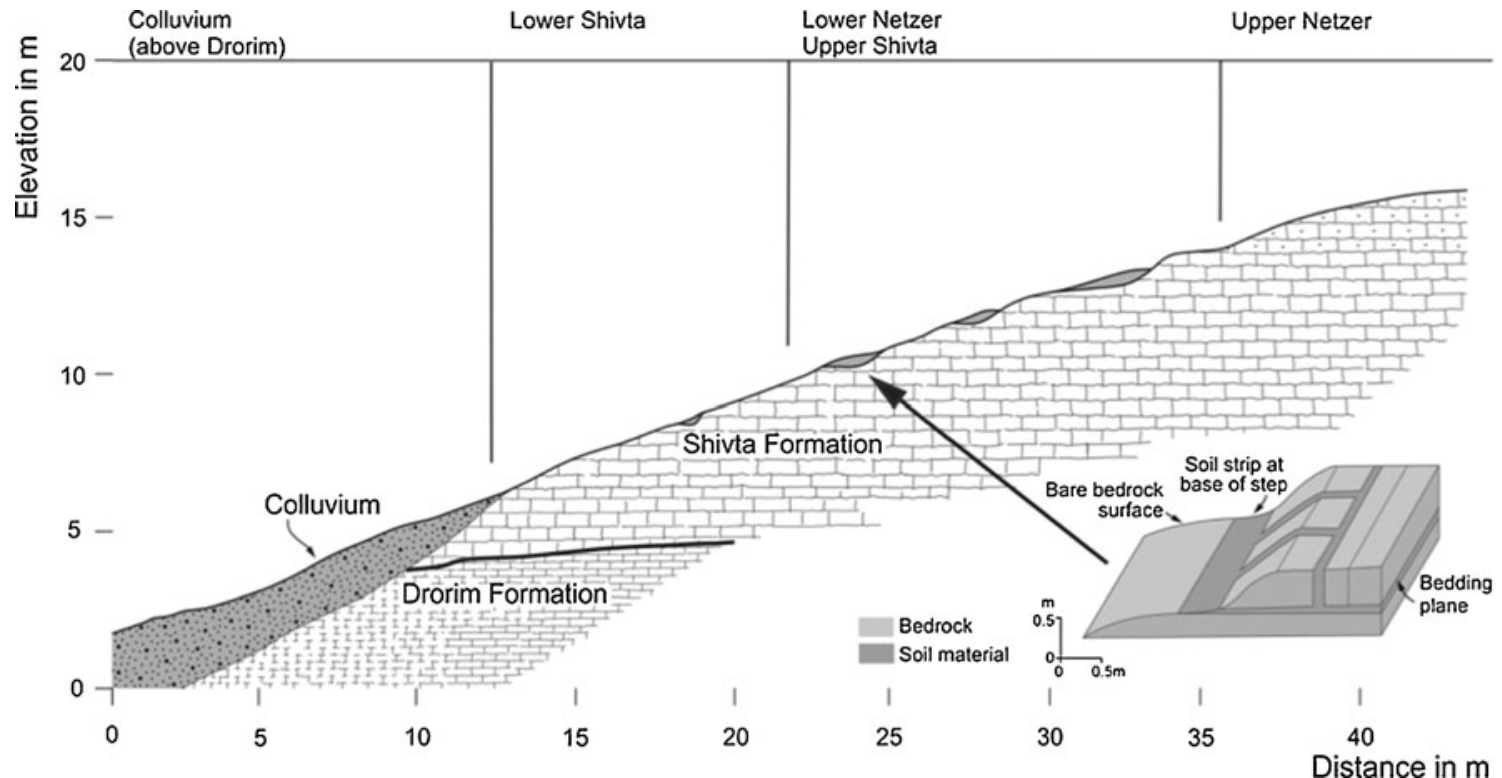

Fig. 2 Geological cross section with lithological formations of the study site modified after Olsvig-Whittaker et al. (1983) 
strongly controlled by the erosion and deposition caused by wind and surface runoff (Olsvig-Whittaker et al. 1983).

Despite the meteorologic aridity, the vegetation of this region is considered to be at the transition of the IranoTuranian plant geographical region and the SaharoArabian region with some Mediterranean components (Danin et al. 1975; Olsvig-Whittaker et al. 1983; Yair and Danin 1980; Yair and Shachak 1982; Zohary 1962). The study area has a range of communities from semi-desert (10-30\% perennial shrubs and semi-shrubs) on the rocky upper north exposed slopes, which are characterized by an unfavorable water regime (Yair and Danin 1980), to some patches of true desert vegetation (less than $10 \%$ perennial cover) on the lower colluvium and southerly exposed slopes. The most favorable water regime prevails in soil pockets and crevices; therefore, vegetation is more or less concentrated along the soil patches and bedrock joints filled with soil. Hence, the study site is very well suited to determine the role of surface ecohydrology for SOC stocks.

\section{Methods}

Based on the aims of the study, the following objectives for field sampling and data analysis are derived: (1) to sample slope sections with different ecohydrologic characteristics (soil and vegetation) to calculate SOC stocks; (2) to compare soil properties, vegetation, SOC concentrations, and SOC stocks for the different ecohydrologic units; and (3) to identify the factors which determine SOC stocks on rocky desert slopes.

\subsection{Ecohydrologic units along rocky desert slopes at Sede Boker}

The study site was mapped based on differences in surface conditions (such as geology, rock/soil ratio, soil distribution, soil bedding, soil depth), microclimate (as indicated by slope gradient and aspect), and vegetation according to Olsvig-Whittaker et al. (1983), Schreiber et al. (1995), and Yair and Raz-Yassif (2004). These factors control the water availability for vegetation and thus determine the ecohydrologic units (EHUs) along the rocky desert slopes. The following units were distinguished for soil sampling and vegetation mapping (Table 1): (1) flat desert pavement (FDP), (2) gently sloped desert pavement (SDP), (3) nonfissured bedrock slope (BS), (4) stepped and fissured bedrock slope (FBS), and (5) slope and valley colluvium (SVC). A detailed description of each unit is given in Table 1. The FDP represents the uppermost unit in the study site, which represents the flat plateau in which the basin is incised. It is characterized by a medium soil and vegetation coverage ( $30 \%)$. The SDP forms the transition from the
FDP to the incised valley. It has a higher soil and vegetation coverage, which is conditioned through the accumulation of aeolian deposits. The bedrock slope, which is located below the SDP, is subdivided into stepped fissured (FBS) and nonfissured bedrock (BS). The FBS shows a characteristic stepped topography with a localized soil cover in small soil pockets and noncontinuous soil strips. The former forms in zones of structural weakness in the Shivta formation and the latter are deposits of fine sediment at the base of the bedrock step below the soil pockets (Yair and Shachak 1982). The vegetation coverage in this unit is generally high. The BS is a massive unit of bedrock with a low density of deep cracks. Soil cover in this unit is generally very shallow and covers only $5-10 \%$. The colluvium, at the base of the slope, can be distinguished in slope colluvium and valley colluvium (SVC). This unit is characterized by a continuous deposition of colluvial sediments, which provide the parent material for the formation of soil. However, soil coverage is still limited due to the presence of large rocks, which cover a significant portion of the surface and inhibit the growth of vegetation and soil formation.

The ecohydrology of these units is strongly influenced by their surface characteristics. Therefore, the soil coverage was classified for each ecohydrologic unit using six soil-cover classes (I: $<1 \%$; II: $1-2 \%$; III: $2-5 \%$; IV: 5-10 \%; V: 10-30\%; and VI: $>30 \%$ ) in the field (compare AG Bodenkunde 2005) and by visual interpretation of photos taken normal to the surface. Rocks larger than $20 \mathrm{~cm}$, which cover the surface and prevent the growth of vegetation, were considered as "bedrock" and were excluded from soil coverage.

Vegetation was mapped and estimated for each ecohydrological unit based on the Braun-Blanquet (McAuliffe 1990) method as well as the plant guide of Zohary (1962) (see Table 1). The vegetation coverage was calculated on total surface (including rock and soils). Larger vegetation coverage than soil coverage is possible due to the canopy effect of the vegetation. Furthermore, we differentiated between the northwest and south exposed slopes, because according to Olsvig-Whittaker et al. (1983), an effect of solar radiation on soil moisture and vegetation and thus on evaporation can be expected on these slopes (Table 2).

\subsection{Soil sampling and data analysis}

To estimate SOC stocks, we took 82 soil samples covering all ecohydrologic units described above at the northeast and south-facing slopes. The number of samples per ecohydrologic unit was arranged to ensure a sufficient amount of samples for each set of relevant ecohydrologic surface properties along a slope (see Table 2). Soil sampling was conducted along a $\mathrm{N}-\mathrm{S}$ transect through the studied valley at sampling sites across each ecohydrologic unit (see Fig. 1) in regular depth intervals $(0-5,5-15,15-20 \mathrm{~cm})$, continuing in 
Table 1 Observed and mapped properties of the ecohydrologic units in the study area Sede Boker according to the findings of OlsvigWhittaker et al. (1983), Schreiber et al. (1995), and Yair and Shachak
(1982). Mean soil depth refers to areas covered by soil, and the rock/ soil ratio is calculated as (100-soil cover)/soil cover

\begin{tabular}{|c|c|c|}
\hline Ecohydrologic unit / general characteristics & Ecohydrologic unit & Mapped characteristics \\
\hline $\begin{array}{l}\text { Flat desert pavement (FDP) } \\
\text { Uppermost unit with thinly bedded limestone and } \\
\text { flint concretions } \\
\text { Very shallow patchy soil and low vegetation coverage } \\
\text { Dominant lithology: upper Netser formation }\end{array}$ & & 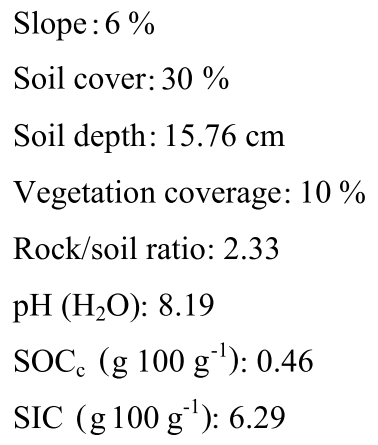 \\
\hline $\begin{array}{l}\text { Gently sloped desert pavement (SDP) } \\
\text { Forms the transition zone from the flat desert } \\
\text { pavement to the incised valley } \\
\text { Higher soil and vegetation coverage than FDP, } \\
\text { accumulation of aeolian deposits } \\
\text { Dominant lithology: upper Netser formation }\end{array}$ & & 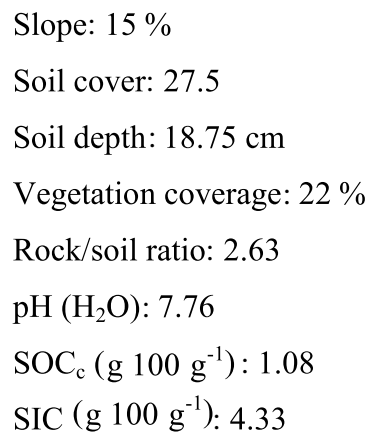 \\
\hline $\begin{array}{l}\text { Stepped and fissured bedrock slope (FBS) } \\
\text { Thinly bedded and densely fissured formation with } \\
\text { stepped topography } \\
\text { Soil accumulated in two different environments: } \\
\qquad \text { (1) concentrated in crevices and fissures } \\
\qquad \text { (2) accumulated in non-contiguous soil patches } \\
\text { (Yair and Shachak 1982) } \\
\text { Dominant lithology: lower Netser and upper Shivta } \\
\text { formation }\end{array}$ & & $\begin{array}{l}\text { Slope: } 20 \% \\
\text { Soil cover: } 45 \% \\
\text { Soil depth: } 20.52 \mathrm{~cm} \\
\text { Vegetation coverage: } 32 \% \\
\text { Rock/soil ratio: } 1.22 \\
\mathrm{pH}\left(\mathrm{H}_{2} \mathrm{O}\right): 7.95 \\
\mathrm{SOC}\left(\mathrm{g} 100 \mathrm{~g}^{-1}\right): 1.09 \\
\mathrm{SIC}\left(\mathrm{g} 100 \mathrm{~g}^{-1}\right): 4.73\end{array}$ \\
\hline
\end{tabular}

intervals of $20 \mathrm{~cm}$ where possible until the profile met bedrock). In addition to SOC concentrations, information of corresponding soil depth, bulk density, and coarse fraction are necessary to estimate SOC stocks (Eq. 1). Soil was sampled with a soil core sampler with a given volume $\left(100 \mathrm{~cm}^{3}\right)$, which allowed the estimation of the soil bulk density BD $\left(\mathrm{g} \mathrm{cm}^{-3}\right)$ based on the total soil weight (in grams) and the volume of the cylinder (in cubic centimeters) (Ravindranath and Ostwald 2008; Rodeghiero et al. 2009). The coarse fraction CF (g $\left.100 \mathrm{~g}^{-1}\right)$ was calculated by the weight of coarse grains $(>2 \mathrm{~mm})$ divided by the total weight of the sample. At sampling sites with very shallow soils, such as weathering planes or depositional patches at the base of the steps, a mixed bag sample of $150 \mathrm{~g}$ was collected for a certain sampling area. In this case, the bulk density was estimated by multiplying the sampling area with the mean soil thickness of the sample.

\subsection{Laboratory and statistical SOC analysis}

Soil analysis was conducted in the laboratories of the University of Basel, Switzerland. The samples were 
Table 1 (continued)

\begin{tabular}{|c|c|c|}
\hline Ecohydrologic unit / general characteristics & Ecohydrologic unit & mapped characteristics \\
\hline $\begin{array}{l}\text { Non-fissured bedrock slope (BS) } \\
\text { Extensive bedrock outcrops of massive limestone } \\
\text { with low density of deep cracks } \\
\text { Bedrock weathers into cobbles and boulders } \\
\text { Soil shallowly accumulated as small soil patches } \\
\text { Dominant lithology: upper Drorim formation }\end{array}$ & $\frac{x-4}{2 x}$ & $\begin{array}{l}\text { Slope: } 21 \% \\
\text { Soil cover: } 7.5 \% \\
\text { Soil depth: } 10 \mathrm{~cm} \\
\text { Vegetation coverage: } 9 \% \\
\text { Rock/soil ratio: } 12.33 \\
\text { pH }\left(\mathrm{H}_{2} \mathrm{O}\right): 8.14\end{array}$ \\
\hline & & $\begin{array}{l}\operatorname{SOC}_{c}\left(g 100 g^{-1}\right): 0.61 \\
\operatorname{SIC}\left(g_{\left.100 g^{-1}\right): 4.37}\right.\end{array}$ \\
\hline $\begin{array}{l}\text { Slope and valley colluvium (SVC) } \\
\text { Soil bedding can be described as a colluvial mantle } \\
\text { Densely jointed and covered with an colluvial } \\
\text { mantle (Dan et al., 1972) } \\
\text { Dominant lithology: lower Drorim formation }\end{array}$ & $\frac{30}{30}$ & 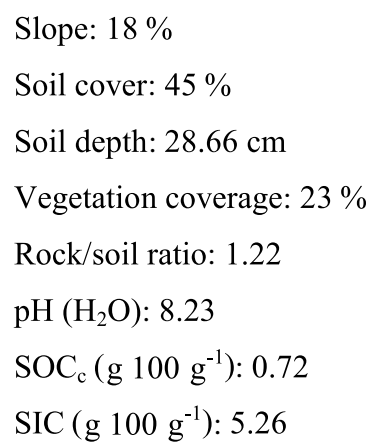 \\
\hline
\end{tabular}

Table 2 Mean soil depth (related to soil-covered areas), median soil, and vegetation coverage and minimum, median, mean, max, and standard deviation of SOC stocks with respect to aspect and ecohydrologic units. The ecohydrological units in the table are ordered according to their sequence along the studied transect (compare Fig. 1). $N$ northern aspect, $S$ southern aspect, $F D P$ flat desert pavement, $S D P$ gently sloped desert pavement, $F B S$ stepped and fissured bedrock slope, $B S$ non-fissured bedrock slope, $S V C$ slope and valley colluvium

Aspect Ecohydrologic unit No. of samples Soil depth $(\mathrm{cm})$ Soil coverage (\%) Vegetation coverage (\%) SOC $_{\text {stock,ehu }}\left(\mathrm{kg} \mathrm{C} \mathrm{m}^{-2}\right)$

Min Median Mean Max STD

\begin{tabular}{|c|c|c|c|c|c|c|c|c|c|c|c|}
\hline $\mathrm{N}$ & FDP & 9 & 15.3 & 30 & 10.5 & & 0.13 & 0.26 & 0.28 & 0.74 & 0.18 \\
\hline $\mathrm{N}$ & SDP & 23 & 12 & 40 & 21 & & 0.06 & 0.56 & 0.72 & 1.90 & 0.55 \\
\hline $\mathrm{N}$ & FBS & 7 & 17 & 45 & 35 & & 0.68 & 1.21 & 1.42 & 3.04 & 0.78 \\
\hline $\mathrm{N}$ & BS & 5 & 12 & 5 & & - & 0.08 & 0.09 & 0.12 & 0.25 & 0.07 \\
\hline- & SVC & 6 & 28.7 & 45 & 23 & & 0.07 & 0.85 & 0.93 & 1.81 & 0.72 \\
\hline S & BS & 8 & 14 & 10 & & - & 0.03 & 0.07 & 0.07 & 0.13 & 0.04 \\
\hline S & FBS & 14 & 19 & 45 & 12 & & 0 & 0.59 & 0.71 & 2.37 & 0.63 \\
\hline $\mathrm{S}$ & SDP & 3 & 23.1 & 15 & 5 & & 0.02 & 0.22 & 0.17 & 0.26 & 0.13 \\
\hline \multirow[t]{2}{*}{ S } & FDP & 7 & 24.7 & 30 & & - & 0.05 & 0.15 & 0.21 & 0.39 & 0.13 \\
\hline & Total & 82 & 18.7 & 29.4 & 24 & & 0 & 0.31 & 0.58 & 3.03 & 0.61 \\
\hline
\end{tabular}


initially dried at $40{ }^{\circ} \mathrm{C}$ and afterwards sieved using a stack of sieves to separate the coarse fraction $(>2 \mathrm{~mm})$, the fine fraction $(<2 \mathrm{~mm})$, and the fraction smaller than $0.032 \mathrm{~mm}$. The latter was subject to further particle size analyses carried out with a SediGraph (SediGraph 5100, Micromeritics). That way, information about the clay fraction was obtained to test its influence on SOC stocks. SOC concentrations were measured using a LECO 100 $\mathrm{CHN}$ analyzer. First, total $\mathrm{C}$ content was measured with the untreated samples. Second, we estimated the SOC content based on the loss of ignition with $500{ }^{\circ} \mathrm{C}$. Third, we calculated the soil inorganic carbon content for the same sample (without organic matter after burning) using again the $\mathrm{CHN}$ analyzer. For each representative layer $\mathrm{i}$ of a soil sample with thickness $d_{\text {soil, i }}$ (in centimeters), SOC stock $\left(\mathrm{SOC}_{\text {stock, }}\right.$, in kilograms of carbon per square meter) was estimated based on Eq. (2):

$$
\begin{aligned}
\mathrm{SOC}_{\text {stock, }, \mathrm{i}}= & 0.1 \times d_{\text {soil, } \mathrm{i}} \times \mathrm{BD} \times \mathrm{SOC}_{\mathrm{ci}} \\
& \times\left(1-\mathrm{CF}_{\mathrm{i}} / 100\right)
\end{aligned}
$$

SOC stocks $\left(\mathrm{SOC}_{\text {stock }}\right)$ per sampling site were then calculated by summarizing the SOC stock of each layer $i$ at the corresponding sampling site:

$\mathrm{SOC}_{\text {stock }}=\sum \mathrm{SOC}_{\text {stock, } \mathrm{i}}$

Based on Eq. (3), SOC stocks are not integrated over a certain reference depth, but for the entire soil column. To consider the limited soil coverage in each ecohydrological unit, we multiplied the stocks given in Eq. (3) with the mean soil coverage of each unit:

$\mathrm{SOC}_{\text {stock, ehu }}=\mathrm{SOC}_{\text {stock }} \times$ soilcoverage

To test the influence of the ecohydrologic units on SOC storage, the factors in the SOC-stock equation (Eq. (3) and the $\mathrm{SOC}_{\text {stock, ehu }}$ (Eq. (4) estimates for each ecohydrologic unit were compared using box-whisker plots. The KruskalWallis test was used to compare the variability of soil properties between ecohydrologic units with the variability within the units. The non-parametric Wilcoxon test for nonnormally distributed variables was additionally used to test for differences of SOC stocks between pairs of ecohydrologic units. In the case of significant difference between the ecohydrological units (e.g., higher variability between the units than within the units), calculated $p$ values are lower than 0.05 (equal to a level of significance of $5 \%$ ). For each ecohydrological unit, averages and standard deviation for each soil property were calculated. The spatial variations were evaluated by the coefficient of variation $\mathrm{CV}$, which is given by the ratio of the standard deviation to the mean value of each soil property. The $\mathrm{CV}$ therefore allows the comparison of the variations of each soil property in different ecohydrologic units through the normalization of the standard deviation.

\section{Results}

4.1 Variability of SOC stocks and controlling soil properties

The results regarding the minima, mean, median, maxima, and standard deviations of the measured soil properties (BD, CF, $\mathrm{SOC}_{\mathrm{c}}$, and $d_{\text {soil }}$ ) and the calculated SOC stocks are summarized in Tables 2 and 3. The largest variability of all SOC-stock controlling variables is displayed by the coarse fraction (CF factor in Eq. (1)), which ranges be-

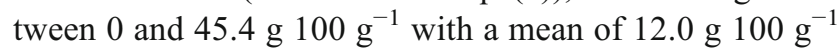
and a coefficient of variation of $81 \%$. $\mathrm{SOC}_{\mathrm{c}}$ shows the second largest variability of the independent variables in

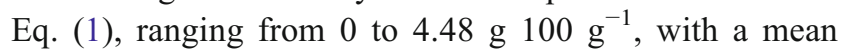

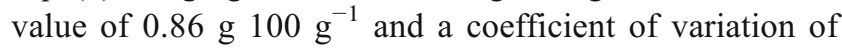
$78.8 \%$. Soil depths range between 5 and $60 \mathrm{~cm}$ with a $\mathrm{CV}$ of $59.5 \%$. The lowest variability of the independent variables in Eq. (1) is shown by BD ranging between 0.56 and $1.90 \mathrm{~g} \mathrm{~cm}^{-3}$, with a mean of $1.30 \mathrm{~g} \mathrm{~cm}^{-3}$ and a $\mathrm{CV}$ of only $20.7 \%$ (see Table 3 ).

The large variability associated with the independent variables of $\mathrm{BD}, \mathrm{CF}, \mathrm{SOC}_{\mathrm{c}}$, and $d_{\text {soil }}$ is propagated through the calculation of the carbon stocks (Eqs. 1, 2, 3, and 4). Calculated SOC stocks show a wide variability ranging from 0 up to $3.03 \mathrm{~kg} \mathrm{C} \mathrm{m}^{-2}$, with a mean of $0.58 \mathrm{~kg} \mathrm{C} \mathrm{m}^{-2}$ and a standard deviation of $0.61 \mathrm{~kg} \mathrm{C} \mathrm{m}^{-2}$. The estimated CV of $105 \%$, which is the largest of the soil properties presented in Table 3, is mainly a result of the large spatial variability associated with the coarse fraction and the SOC concentration.

\subsection{SOC stocks, soil properties, and ecohydrology}

The median SOC concentration shows strong differences between the north- and the south-facing slopes (Fig. 3) and a tendency of increasing concentration downslope from the N-FDP to the N-FBS (Fig. 4a). As a combination of differences in aspect and the downslope increase, the greatest SOC concentrations are shown in the north-facing FBS (see Fig. 4q). Soil depths are higher on the S-facing slope and lowest on the N-facing slope (see Figs. $3 \mathrm{c}$ and $4 \mathrm{~b}$ ). Maximum soil depths and variability are observed in unit SVC, which is generally covered by a layer of colluvial deposits (up to $50 \mathrm{~cm}$ ). Somewhat lower soil depths are observed at unit FDP of the northern exposed slope, while at the southern slope, this unit is characterized by higher values. As suggested by the Kruskal-Wallis test $(p$ value $=$ 0.19 ), differences of soil depth between ecohydrological units are not significant (see Fig. 4b). In contrast, significant 
Table 3 Minima, median, mean, maxima, and standard deviation of measured soil properties relevant for the calculation of the SOC stock

\begin{tabular}{|c|c|c|c|c|c|c|}
\hline Parameter & Min & Median & Mean & Max & STD & $\mathrm{STD} /$ mean $(\%)$ \\
\hline $\mathrm{BD}\left(\mathrm{g} \mathrm{cm}^{-3}\right)$ & 0.56 & 1.30 & 1.30 & 1.90 & 0.27 & 20.7 \\
\hline $\mathrm{CF}\left(\mathrm{g} 100 \mathrm{~g}^{-1}\right)$ & 0 & 10.38 & 12.02 & 45.42 & 9.74 & 81.0 \\
\hline $\mathrm{SOC}_{\mathrm{c}}\left(\mathrm{g} 100 \mathrm{~g}^{-1}\right)$ & 0 & 0.67 & 0.86 & 4.48 & 0.68 & 78.8 \\
\hline $\mathrm{SOC}_{\text {stock, ehu }}\left(\mathrm{kg} \mathrm{C} \mathrm{m}^{-2}\right)$ & 0 & 0.31 & 0.58 & 3.03 & 0.61 & 105.17 \\
\hline Soil depth (cm) & 5 & 15 & 18.7 & 60 & 11.12 & 59.46 \\
\hline
\end{tabular}

Values are calculated using the entire dataset $(n=82)$. Mean soil depth refers to areas covered by soils. According to Eq. 4 , SOC stocks refer to the entire area of the study site

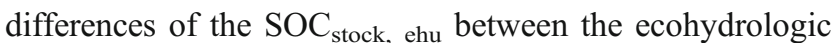
units are confirmed by the $p$ values derived from the KruskalWallis test and the non-parametric Wilcoxon test (see Fig. 4c). The Wilcoxon test indicates that the EHUs cannot be stratified into clearly defined statistical groups according to their SOC stock. SOC stocks of the N-FBS unit are significantly higher than the other EHUs (expect for the SVC), but other EHUs do not classify into groups that are defined by major gaps of SOC stock in between. The trend along the transect (from N-FDP to S-FDP) is similar to the SOC concentration (see Fig. 4a) and dissimilar to the soil depths given in Fig. 4b. The mean vegetation coverage (see Fig. $4 d$ and Table 2) is characterized by the largest differences between the aspect and the ecohydrologic units. The trend of the vegetation coverage along the different ecohydrologic units (see Fig. 4d) is similar to the trend of the SOC concentration and stock (see Fig. 4a, c). The lowest median vegetation coverage is observed at the southern SDP (5\%) and the highest median coverage at the northern exposed FBS (35\%) (see Fig. 4d and Table 2).

The clay fraction in all soil samples ranged from 9.05 to $16.61 \%$, with a mean of $13.23 \%$ and a standard deviation of 2.32. No significant differences in average clay content between ecohydrologic units were identified, which suggests that clay content had only a minor effect on SOC stocks.

Measured SOC contents do not exhibit a notable vertical gradient at a point (Fig. 5). The SOC concentrations in the upper $40 \mathrm{~cm}$ of the soil are characterized by a strong variability, without any detectable trend. Below $40 \mathrm{~cm}$, SOC concentrations are somewhat lower, with a smaller variability.

\section{Discussion}

\subsection{SOC stock, surface characteristics, and vegetation}

The very strong control of vegetation on the SOC concentration and $\mathrm{SOC}_{\text {stock, ehu }}$ is revealed by their similar pattern on different aspects (see Fig. 3) and in the ecohydrologic units (see Fig. 4). Mean SOC concentrations and stocks strongly correlate with vegetation coverage in each ecohydrologic unit $\left(R^{2}=0.8\right.$ and 0.9 , respectively, Fig. 6a and b). The highest SOC concentration and $\mathrm{SOC}_{\text {stocks, ehu }}$ are found at slope exposures that favor high soil moisture and thus a

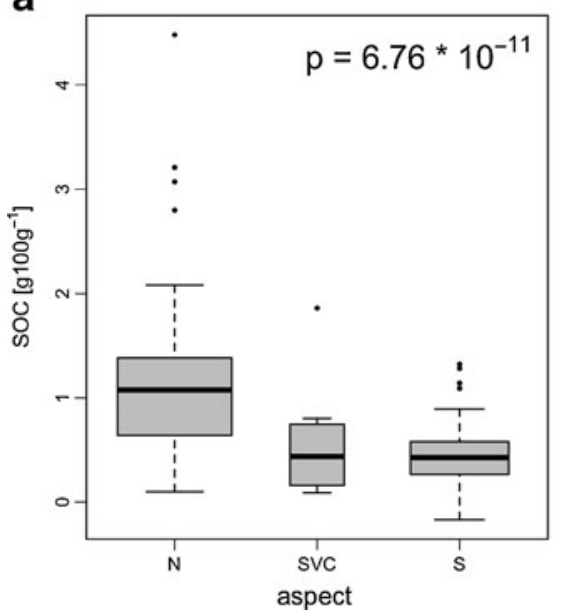

b

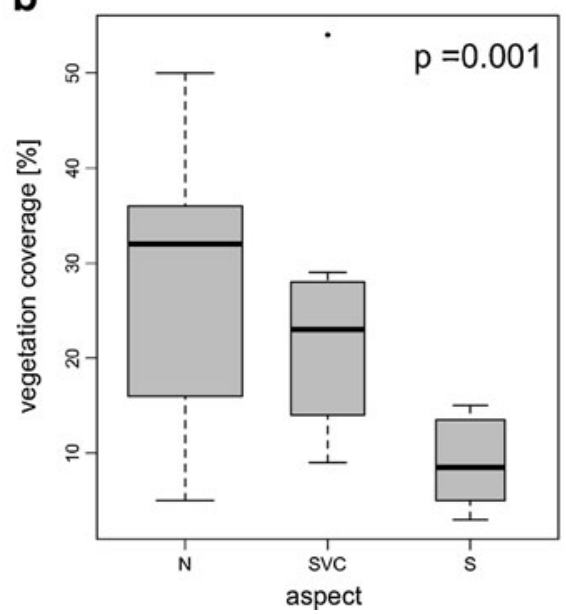

C

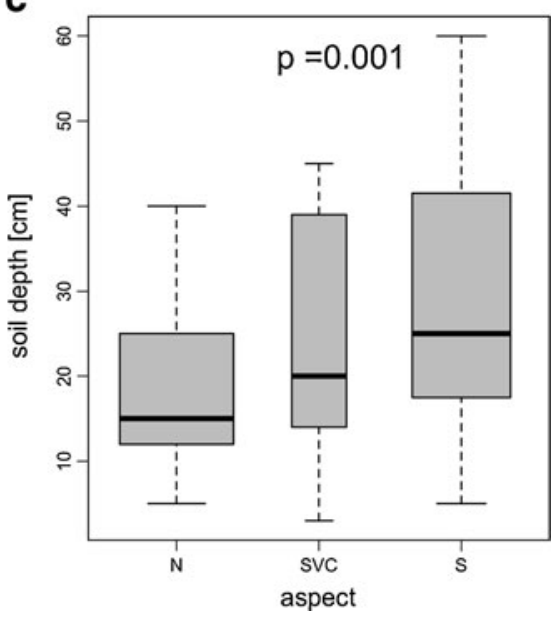

Fig. 3 SOC concentration (g $100 \mathrm{~g}^{-1}$ ) (a), vegetation coverage (in percent) (b), and soil depth (in centimeters) (c) with respect to aspect from the whole investigation area. $N$ and $S$ indicated northern and southern aspects, respectively. The boxes have widths proportional to the number of sampling points in each box (number of total measurements, 82) 


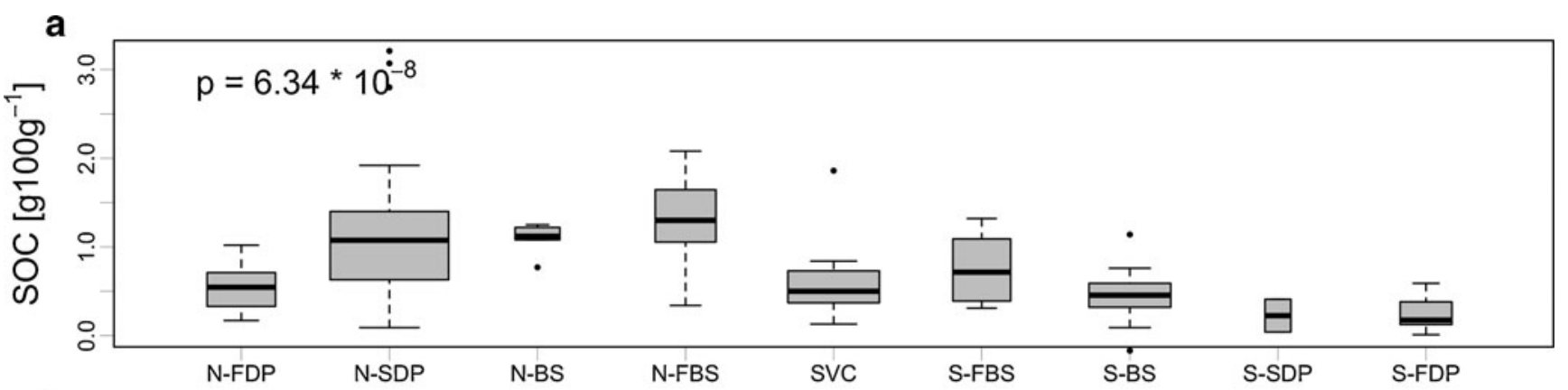

b
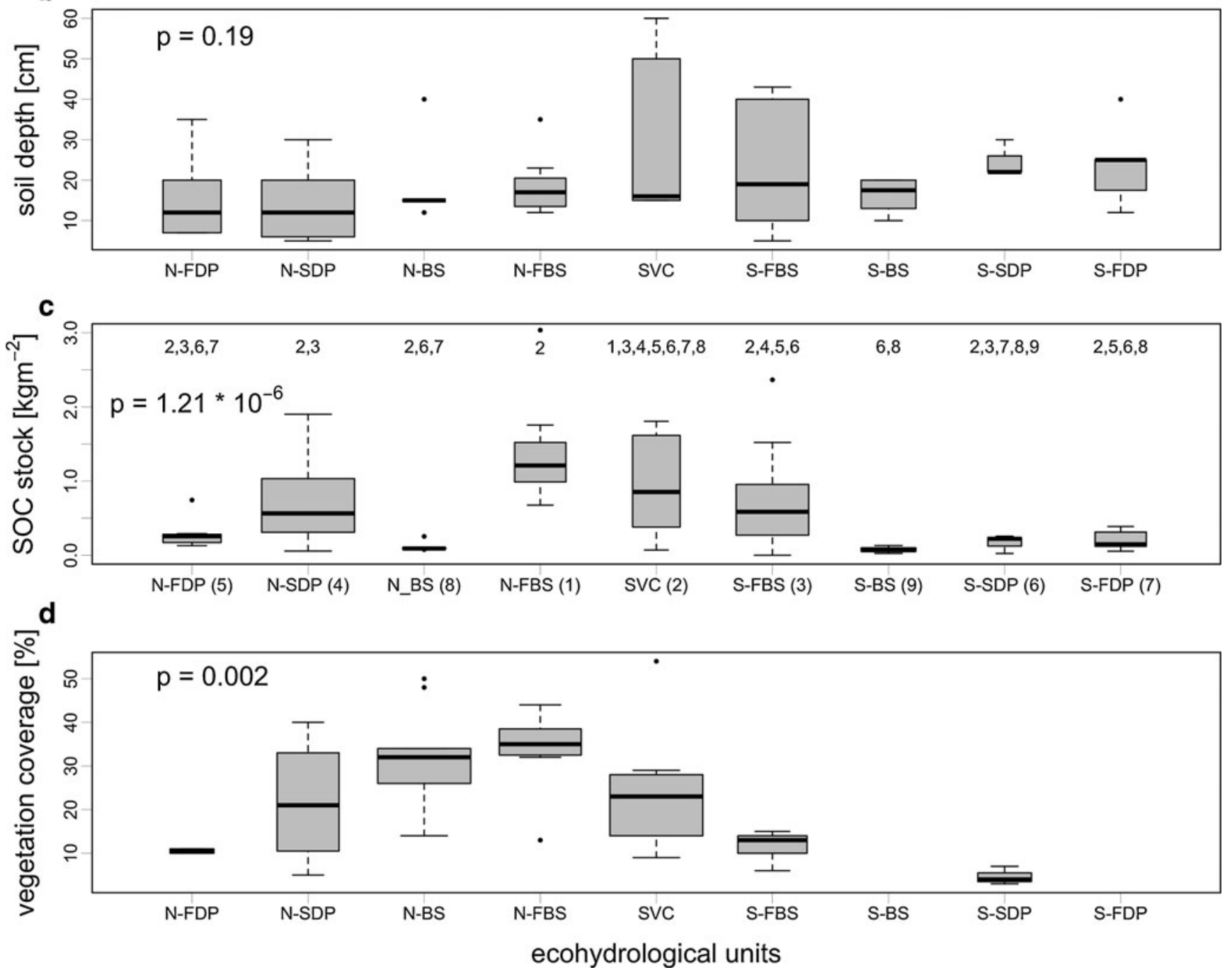

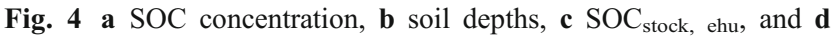
vegetation coverage, $\mathbf{d}$ with respect to correspondence ecohydrologic unit and aspect. $N$ and $S$ indicated northern and southern aspect, respectively. FDP flat desert pavement with significant higher soil cover and depth due to minor slope gradient, $S D P$ gently sloped desert pavement with lower soil depth due to higher slope gradient, $F B S$ stepped and fissured bedrock slope, $B S$ non-fissured bedrock slope, $S V C$ slope and valley colluvium. Ecohydrologic units are ordered in correspondence to their locations from $\mathrm{N}$ to $\mathrm{S}$ along the transect. The numbers in brackets

high vegetation densities (e.g., northern exposed slopes and lower slope positions, Figs. 3 and 4). In contrast, the mean following the EHU names of Fig. 4c denote the rank of the EHU (e.g., the highest median of N-FBS is given by (1), the lowest for S-BS given by (9)). The numbers above the boxes denote EHUs (according to their rank) with a similar SOC-stock distribution (as given by $p>0.05$ using the nonparametric Wilcoxon test). The boxes have widths proportional to the number of sampling points in each box (number of total measurements, 82). The $p$ values are derived using the Kruskal-Wallis test and give significant differences between EHUs in case $p<0.05$

soil depth of the ecohydrologic units correlates only very weakly with SOC concentration (see Fig. 6c), and no 


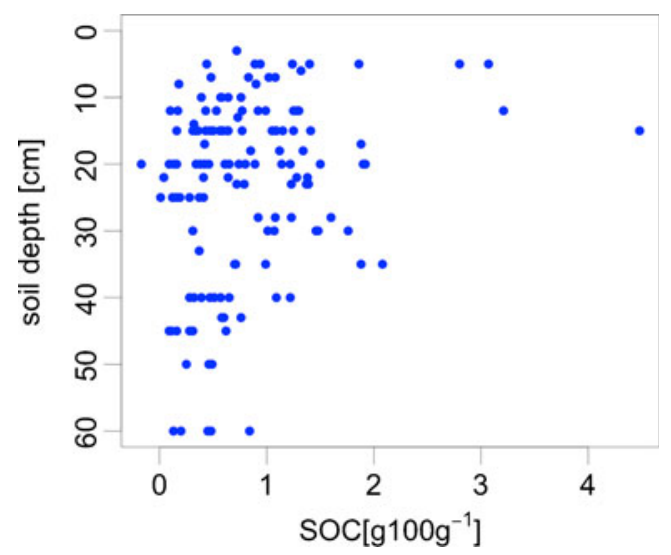

Fig. 5 SOC concentration as a function of depth below surface, plotted for every sample $(n=82)$

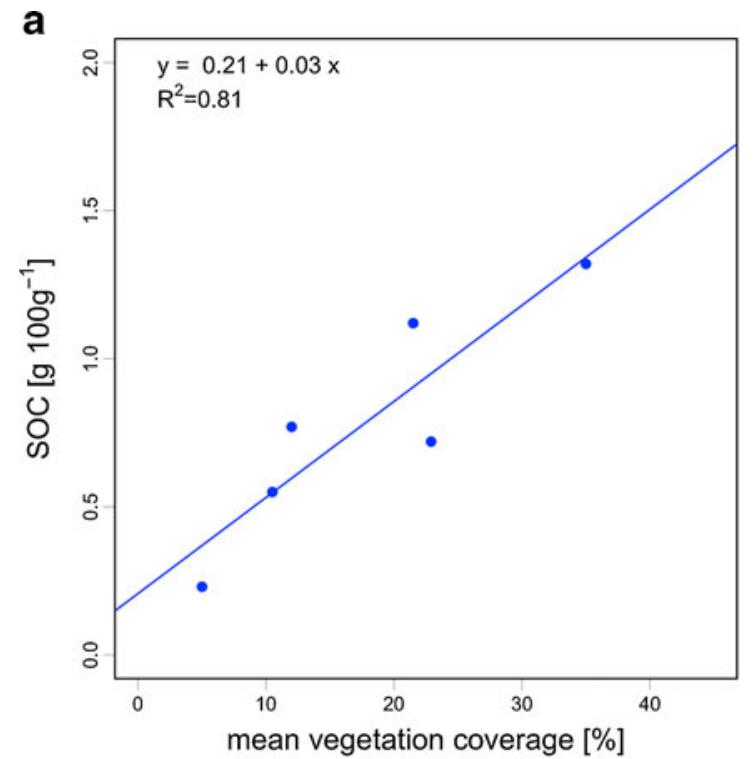

b

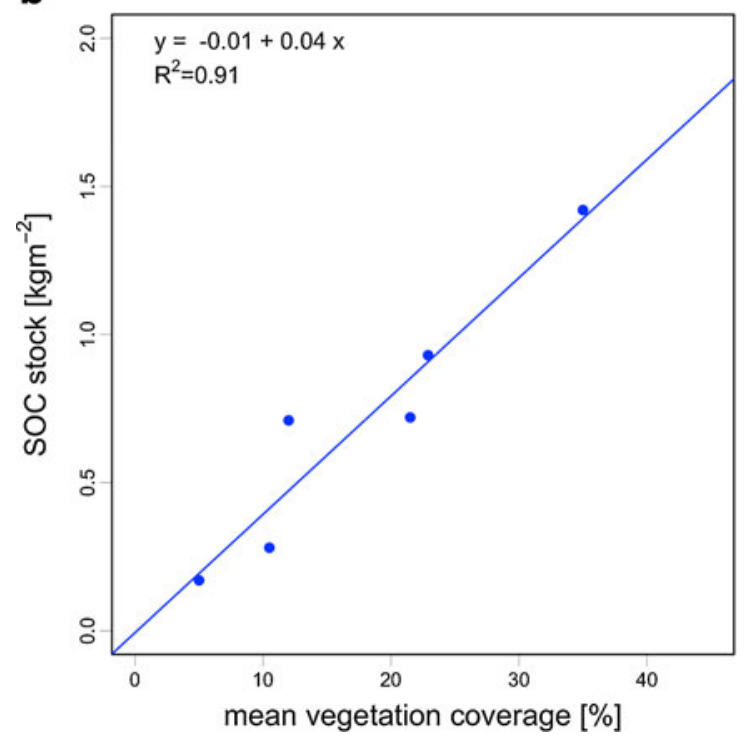

correlation is found between soil depth and $\mathrm{SOC}_{\text {stock, ehu }}$ (see Fig. 6d). Thus, aspect-driven microclimatic effects that control soil moisture and vegetation coverage appear to affect SOC stocks more strongly than soil depth. The lacking relevance of soil thickness on rocky desert slopes is in strong contrast to its importance for SOC stocks in more humid areas (Berhe et al. 2008; Yoo et al. 2006). The positive relationship between vegetation coverage and SOC stocks at Sede Boker shows that the findings of Olsvig-Whittaker et al. (1983), who studied the effects of surface properties on vegetation, can also be applied to SOC stocks. Our results suggest that the different ecohydrologic conditions along rocky desert slopes near Sede Boker identified by Olsvig-Whittaker et al. (1983), Schreiber et al.

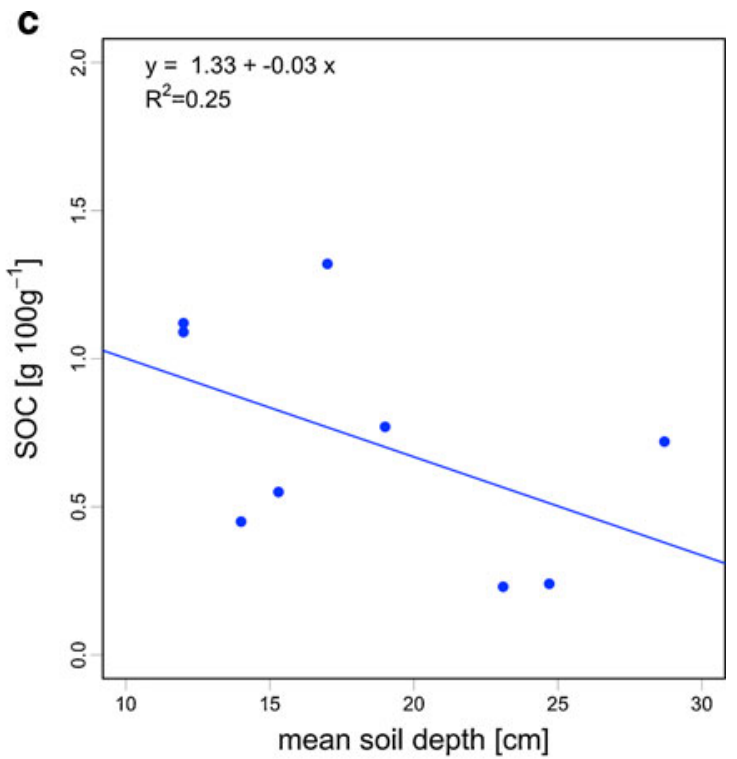

d

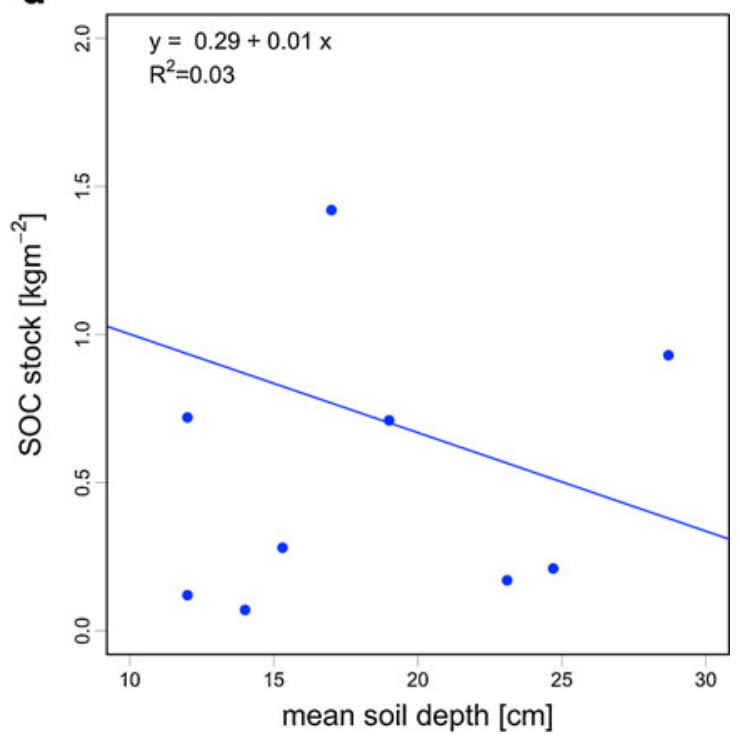

Fig. 6 Scatterplot of SOC concentration $(\mathbf{a}, \mathbf{c})$ and $\mathrm{SOC}_{\text {stock, ehu }}(\mathbf{b}, \mathbf{d})$ of sampled soils versus vegetation coverage and soil depth. Values are mean values obtained for each ecohydrologic unit 
(1995), and Yair and Raz-Yassif (2004) also affect the SOC stocks on the different units. A similar effect is reported by Li et al. (2010) and Jobbágy and Jackson (2000) who both found a strong link between aboveground vegetation properties (e.g., density, type, stand age) and SOC. Our results also suggest that vegetation coverage provides a direct index for the spatial pattern of SOC stocks in drylands.

\subsection{Surface processes and SOC stocks}

The variability of the soil properties and the SOC stocks at Sede Boker is associated with differences in slope aspect (see Fig. 3) and NPP of the ecohydrologic units along the rocky desert slopes (see Fig. 4, Tables 2 and 3). In accordance with Olsvig-Whittaker et al. (1983), these results imply a positive dependency of SOC stocks on the relative moisture supply, which is given by surface runoff and aspect-driven differences of evaporation. The discontinuity of runoff associated with the patchwork of water sources and sinks also affects the distribution of SOC in the soil profile. In undisturbed soils, a strong vertical SOC gradient between topsoil and bottom soil is common (Arrouays and Pelissier 1994; Mishra et al. 2009; Wang et al. 2004). At Sede Boker, fine sediments provide the bulk substrate for soil formation and are preferentially deposited in small depressions and bedrock fissures, which act as local sediment sinks (see Figs. 1 and 2) (Olsvig-Whittaker et al. 1983; Yair and Danin 1980). Soil depth therefore varies on a centimeter to meter scale due to the spatial pattern of bedrock surface morphology. Eroded topsoils, which are generally enriched in SOC, are deposited in these fissures and may be stored over a long period of time. The limited change of SOC concentration with depth (see Fig. 5) at our sampling sites is in agreement with strong SOC redistribution and deposition at Sede Boker. Thus, the relationship of SOC content and soil depth appears to be strongly influenced by lateral soil movement, highlighting the need to consider soil as a mobile layer, formed by selective erosion and deposition (Hoffmann et al. 2009; Kuhn et al. 2009), which varies in time through changing source areas and/or the changing soil conditions in the source area (Dotterweich 2008).

\subsection{SOC-stock comparison with other drylands}

Table 4 summarizes results of SOC studies in arid and semiarid areas, regarding the measured SOC concentrations and stocks. The estimated $\mathrm{SOC}_{\text {stocks, ehu }}$ of the Sede Boker study area are in a similar range, while SOC concentrations are generally greater than those in other arid environments (see Table 4). Because $\mathrm{SOC}_{\text {stocks, ehu }}$ refer to the entire study site and SOC concentrations to places in which soils are developed, the similar spatial pattern of $\mathrm{SOC}_{\text {stocks, ehu }}$ and

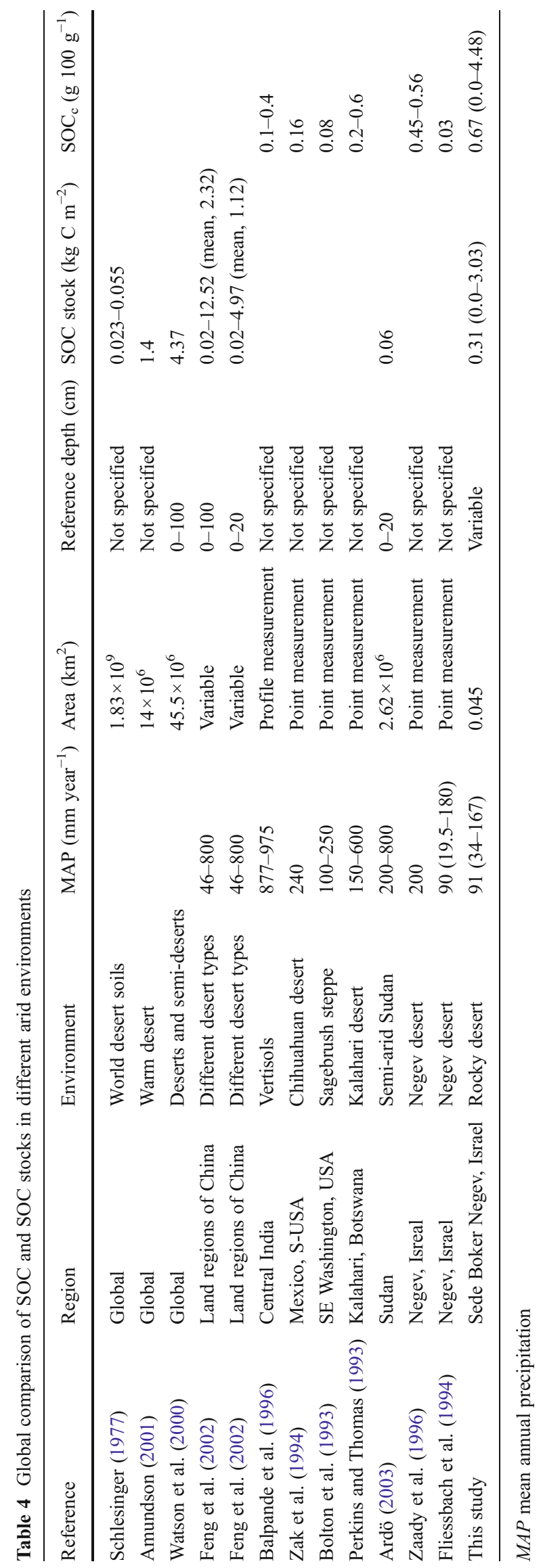


increased SOC concentrations are attributed to the patchiness of soil cover in our study area compared to other areas cited in Table 4. While large fractions of our study area have rocky surfaces, sites with soil cover also carry vegetation and thus increased SOC concentrations. This is in accordance to the "islands of fertility" (Schlesinger and Pilmanis 1998) with increased biogeochemical processes, NPP, and SOC concentrations. Furthermore, higher concentrations in our study site might be attributed to the reduced mineralization of SOC, due to the lack of water in the Negev desert (Yao et al. 2010) and/or the degradation of soil due to overgrazing (compare for instance Bolton et al. 1993) in some of the other sites mentioned in Table 4. The comparison of our study to those presented in Table 4 remains limited. The studies presented in Table 4 rely on different measurement techniques of the SOC, different upscaling approaches, and variable reference soil depths taken into account. Unfortunately, reference soil depths are only given for 4 of the 13 case studies. Differences in SOC stocks may thus not represent environmental conditions, but simply the different methodologies applied for inventorying. The comparison indicates that the number of high-resolution SOC inventories in arid environments is very limited, and more case studies using a comparable methodology are necessary to evaluate the importance and potential changes of SOC in arid environments. In any case, on a global scale, the rela-

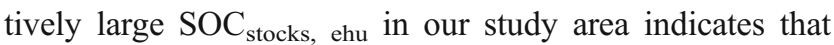
soils in arid environments, especially in rocky deserts associated with hardly any soil cover, may comprise a significant SOC pool that is sensitive to NPP. Even the admittedly somewhat arbitrarily calculated average soil depth of $18 \mathrm{~cm}$ is also in contrast to the notion that rocky deserts do not contain significant soil cover and thus SOC.

\section{Conclusions}

This study aimed at identifying the relationship between surface characteristics, vegetation coverage, and SOC concentration and stocks in the arid northern Negev in Israel. Soils cover $30 \%$ of the study area, and the soil-covered areas are on average $18 \mathrm{~cm}$ deep and contained similar concentrations of SOC than soils from more humid drylands. However, the results show a large spatial variability of SOC, soil bulk density, and soil thickness. Consequently, the estimated SOC stock ranges between 0 and $3.03 \mathrm{~kg} \mathrm{C} \mathrm{m}^{-2}$ with a mean of $0.58 \mathrm{~kg} \mathrm{C} \mathrm{m}^{-2}$ (median, $0.31 \mathrm{~kg} \mathrm{C} \mathrm{m}^{-2}$ ) and a standard deviation of $0.61 \mathrm{~kg} \mathrm{C} \mathrm{m}^{-2}$. The differences in SOC stocks between ecohydrologic units on the north- and south-facing slopes indicate the relevance of eco-climate and thus the potential impact of climate change on rocky desert SOC stocks. They confirm that conceptual approaches, which explain the spatial patterns of vegetation cover on rocky desert slopes in the Negev, can also be applied to SOC stocks. In addition to climate-driven differences between aspect and slope position, the ecohydrologic units take changes of small-scale surface properties into account. The small-scale variability is mainly caused by lithology-driven differences of the microtopography, which provides accommodation space in fissures and on bedrock steps, for fine sediment accumulation and soil formation. Thus, significant differences of SOC stocks as well as vegetation densities between ecohydrologic units demonstrate that small-scale surface properties modulate climate-driven differences and provide a further control on the presence or absence of soils and thus on the amount of SOC storage.

In more general terms, our results show that dryland soils contain a significant amount of SOC even in arid regions. Even this amount is smaller than in more humid environments; it is of major importance for the functioning and thus conservation of arid ecosystem. Differences in eco-climate, microtopography, surface processes, soil formation and properties, and vegetation between the ecohydrologic units are apparently of greatest importance for SOC stocks in drylands. The results strongly suggest that the microscale (decimeter to meter) water supply and NPP, as indicated by the vegetation coverage, determine SOC stocks on rocky desert slopes. The variability of SOC stocks, driven by aspect, soil moisture availability, and vegetation coverage, also implies that SOC stocks in arid environments are highly sensitive to climate change and thus represent a major unstable $\mathrm{C}$ pool within the global carbon cycle of the twenty-first century.

Acknowledgments We owe our gratitude to the Freiwillige Akademische Gesellschaft (FAG) Basel and the University of Basel for funding the field work in Sede Boker.

\section{References}

Amundson R (2001) The carbon budget in soils. Ann Rev Earth Planet Sci 29:535-562

Ardö JLO (2003) Assessment of soil organic carbon in semi-arid Sudan using GIS and the CENTURY model. J Arid Environ 54:633-651

Arkin Y, Braun M (1965) Type sections of upper cretaceous formations in the northern Negev (southern Israel). Israel Geol. Survey Stratigraphic Section, No.2a, Jerusalem, pp 1-19

Arrouays D, Pelissier P (1994) Modeling carbon storage profiles in temperate forest humic loamy soils of France. Soil Sci 157:185-192

Asner GP, Borghi CE, Ojeda RA (2003) Desertification in Central Argentina: changes in ecosystem carbon and nitrogen from imaging spectroscopy. Ecol Appl 13:629-648

Balpande SS, Deshpande SB, Pal DK (1996) Factors and processes of soil degradation in Vertisols of the Purna Valley, Maharashtra, India. Land Degrad Dev 7:313-324

Berhe AA, Harden JW, Torn MS, Harte J (2008) Linking soil organic matter dynamics and erosion-induced terrestrial carbon sequestration at different landform positions. J Geophys Res 113:1-12 
AG Bodenkunde (2005) Bodenkundliche Kartieranleitung KA 5 (German Soil Mapping Guide, 5th edition), Bundesanstalt für Geowissenschaften und Rohstoffe und Geologische Landesämter der Bundesrepublik Deutschland (Federal Institute for Geosciences and Natural Resources and Geological Survey offices of the Federal Republic of Germany) (eds.), Hannover, pp. 438

Bolton H, Smith JL, Link SO (1993) Soil microbial biomass and activity of a disturbed and undisturbed shrub-steppe ecosystem. Soil Biol Biochem 25:545-552

Branchu P, Faure H, Ambrost JP, Bakker EMV, Fauredenard L (1993) Africa as source and sink for atmospheric carbon dioxide. Glob Planet Chang 7:41-49

Bruins HJ (1986) Desert environment and agriculture in the Central Negev and Kadesh-Barnea during historical times. Ph.D. thesis, Agricultural University Wageningen. Midbur Foundation, Nijkerk, the Netherlands

Dan J, Yaalon DH, Koyumdjiski H, Raz Z (1972) The soil association map of Israel. Israel J Earth Sci 21:29-49

Danin A, Orshan G, Zohary M (1975) The vegetation of the northern Negev and the Judean Desert of Israel. Israel J Bot Basic Appl Plant Sci 24:118-172

Dotterweich M (2008) The history of soil erosion and fluvial deposits in small catchments of Central Europe: deciphering the long term interaction between human and the environment-a review. Geomorphology 101:192-208

Egli M, Sartori G, Mirabella A, Favilli F, Giaccai D, Delbos E (2009) Effect of north and south exposure on organic matter in high Alpine soils. Geoderma 149:124-136

Evenari M, Masig D, Rogel A (1980) Runoff-farming in the Negev Desert of Israel (VI). Jacob Blaustein Institute for Desert Research, Sede Boker

Fang C, Moncrieff JB (2001) The dependence of soil $\mathrm{CO}_{2}$ efflux on temperature. Soil Biol Biochem 33:155-165

FAO (ed) (2004) Carbon sequestration in dryland soil. World soil resources reports 102, Rome. Available at: http://www.fao.org/ docrep/007/y5738e/y5738e00.htm. Accessed Febuary 2012

Farage P, Pretty J, Ball A (2003) Biophysical aspects of carbon sequestration in drylands. Seminar paper presented at University of Essex, Feb 3, 1-25 pp

Feng Q, Endo KN, Guodong C (2002) Soil carbon in desertified land in relation to site characteristics. Geoderma 106:21-43

Fliessbach A, Sarig S, Steinberger Y (1994) Effects of water pulses and climate conditions on microbial biomass kinetics and microbial activity in yermosol of Central Negev. Arid Soil Res Rehab 8:353-362

Glatzel S, Sommer M (2005) Colluvial soils and landscape position: field studies on greenhouse gas exchange and related ecological characteristics. Z Geomorphol 139:87-99

Glenn E, Squired V, Olson M, Frye R (1993) Potential for carbon sequestration in the drylands. Water Air Soil Pollut 70:341-355

Goidts E, van Wesemael B (2007) Regional assessment of soil organic carbon changes under agriculture in Southern Belgium (19552005). Geoderma 141:341-354

Grieve IC (2001) Human impacts on soil properties and their implications for the sensitivity of soil systems in Scotland. Catena 42:361-374

Griffiths RP, Madritch MD, Swanson AK (2009) The effects of topography on forest soil characteristics in the Oregon Cascade Mountains (USA): implications for the effects of climate change on soil properties. For Ecol Manag 257:1-7

Hoffmann T, Glatzel S, Dikau R (2009) A carbon storage perspective on alluvial sediment storage in the Rhine catchment. Geomorphology 108:127-137

Houghton RA (2007) Balancing the global carbon budget. Ann Rev Earth Planet Sci 35:313-347

IPCC (2007) Chapter 7: Couplings between changes in the climate system and biogeochemistry. In: Climate Change 2007: The physical science basis. Contribution of Working Group I to the Fourth Assessment Report of the Intergovernmental Panel on Climate Change. Cambridge University Press, Cambridge

IUSS Working Group WRB (2006) World reference base for soil resources 2006. World soil resources reports no. 103. FAO, Rome

Jobbágy EG, Jackson RB (2000) The vertical distribution of soil organic carbon and its relation to climate and vegetation. Ecol Appl 10:423-436

Kirschbaum MUF (2000) Will changes in soil organic carbon act as a positive or negative feedback on global warming? Biogeochemistry 48:21-51

Kuhn NJ, Yair A (2004) Spatial distribution of surface conditions and runoff generation in small arid watersheds, Zin Valley Badlands, Israel. Geomorphology 57:183-200

Kuhn NJ, Hoffmann T, Schwanghart W, Dotterweich M (2009) Agricultural soil erosion and global carbon cycle: controversy over? Earth Surf Proc Land 34:1033-1038

Laity J (2008) Deserts and desert environments. Wiley-Blackwell, Singapore, $\mathrm{p} 342$

Lal R (2003) Carbon sequestration in dryland ecosystems. Environ Manage 33:528-544

Lal R (2005) Soil erosion and carbon dynamics. Soil Tillage Res $81: 137-142$

Lal R (2009) Sequestering carbon in soils of arid ecosystems. Land Degrad Dev 20:441-454

Lal R, Kimble JM, Stewart BA (2001) Importance of soil bulk density and methods of its measurement. In: Kimble JM, Follett RF, Stewart BA (eds) Assessment methods for soil carbon. CRC Press, Boca Raton, pp 31-44

Leifeld J, Bassin S, Fuhrer J (2005) Carbon stocks in Swiss agricultural soils predicted by land-use, soil characteristics, and altitude. Agr Ecosyst Environ 105:255-266

Li P, Wang Q, Endo T, Zhao X, Kakubari Y (2010) Soil organic carbon stock is closely related to aboveground vegetation properties in cold-temperate mountainous forests. Geoderma 154:407-441

McAuliffe JR (1990) A rapid survey method for the estimation of denisty and cover in desert plant communities. J Veg Sci 1:653656

Michaelides K, Chappell A (2009) Connectivity as a concept for characterising hydrological behaviour. Hydrol Process 23:517-522

Mishra U, Lal R, Slater BK, Calhoun F, Liu D, Van Meirvenne M (2009) Predicting soil organic carbon stock using profile depth distribution functions and ordinary kriging. Soil Sci Soc Am J 73:614-621

Olsvig-Whittaker L, Shachak M, Yair A (1983) Vegetation patterns related to environmental factors in a Negev Desert watershed. Vegetation 54:153-165

Parsons AJ, Abrahams AD (eds) (2009) Geomorphology of desert environments, 2nd edn. Springer, New York

Perkins JS, Thomas DSG (1993) Spreading deserts or spatially confined environments? Land degradation and cattle ranching in the Kalahari Desert of Botswana. Land Degrad Rehabil 4:179-194

Qi Y, Xu M, Wu J (2002) Temperature sensitivity of soil respiration and its effects on ecosystem carbon budget: nonlinearity begets surprises. Ecol Model 153:131-142

Quinton JN, Govers G, Van Oost K, Bardgett RD (2010) The impact of agricultural soil erosion on biogeochemical cycling. Nat Geosci $3: 311-314$

Ravindranath NH, Ostwald M (2008) Carbon inventory methods. Handbook for greenhouse gas inventory, carbon mitigation and roundwood production projects. Advances in global change research 29. Springer Science + Business Media B.V, Dordrecht, $308 \mathrm{pp}$

Reifenberg A (1947) The soils of Palestine. Murby, London, p 106

Rodeghiero M, Heinemeyer A, Schrumpf M, Bellamy P (2009) Determination of soil carbon stocks and changes. In: Kutsch WLB, 
Heinemeyer A (eds) Soil carbon dynamics. An integrated methodology. Cambridge University Press, New York, pp 49-75

Rosenbloom NA, Harden JW, Neff JC, Schimel DS (2006) Geomorphic control of landscape carbon accumulation. J Geophys Res 111:1-10

Rotenberg E, Yakir D (2010) Contribution of semi-arid forests to the climate system. Science 327:451

Sarmiento JL, Gruber N (2002) Sinks for anthropogenic carbon. American Institute of Physics

Schimel DS (2010) Drylands in the earth system. Science 327 (5964):418-419

Schimel D, Enting IG, Heimann M, Wigley TML, Raynaud D, Alves D, Siegenthaler U (1994) $\mathrm{CO}_{2}$ and the carbon cycle. Extracted from the Intergovernmental Panel on Climate Change (IPCC Report, "Climate Change, 1994"). In: Wigley TMLS (ed) The carbon cycle. Cambridge University Press, New York, pp 7-36

Schimel D, Melillo J, Tian H (2000) Contribution of increasing $\mathrm{CO}_{2}$ and climate to carbon storage by ecosystems in the United States. Science 287:2004-2006

Schlesinger WH (1977) Carbon balance in terrestrial detritus. Annu Rev Ecol Syst 8:51-81

Schlesinger WH (1990) Evidence from chronosequence studies for a low carbon-storage potential of soils. Nature 348:232-234

Schlesinger WH (1991) Biogeochemistry: an analysis of global change. Academic, San Diego, p 588

Schlesinger WH, Pilmanis AM (1998) Plant-soil interactions in deserts. Biogeochemistry 42:169-187

Schlesinger WH, Raikes JA, Hartley AE, Cross AF (1996) On the spatial pattern of soil nutrients in desert. Ecosyst Ecol 77:364-374

Schreiber KF, Yair A, Shachak M (1995) Ecological gradients along slopes of the Northern Negev Highlands, Israel. Catena Adv Geoecol 28:209-229

Seip HM (2001) We know too little about the carbon cycle. Cicerone (1), Oslo, p 6

Smith JE, Heath LS (2002) A model of forest floor carbon mass for United States forest types. Newtown Square, PA: U.S. Department of Agriculture, Forest Service, Northeastern Research Station, Newtown Square PA. Research Paper NE$722,37 \mathrm{pp}$

Tan ZX, Lal R, Smeck NE, Calhoun FG (2004) Relationships between surface organic carbon pool and site variables. Geoderma 121:187-195

Tsui C-C, Chen Z-S, Hsieh C-F (2004) Relationships between soil properties and slope position in a lowland rain forest of southern Taiwan. Geoderma 123:131-142

van Wesemael B, Paustian K, Meersmans J, Goidts E, Barancikova G, Easter M (2010) Agricultural management explains historic changes in regional soil carbon stocks. Proc Natl Acad Sci 107:14926-14930
Wang S, Huang M, Shao X, Mickler RA, Li K, Ji J (2004) Vertical distribution of soil organic carbon in China. Environ Manage 33:200-209

Watson RT, Noble IR, Bolin B, Ravindranath NH, Verardo DJ, Dokken DJ (eds) (2000) Land use, land-use change, and forestry. A special report of the IPCC. Cambridge University Press, Cambridge

Wigley TML, Schimel DF (eds) (2005) The carbon cycle. Cambridge University Press, Cambridge. 312 pp

Yaalon DH, Dan J (1974) Accumulation and distribution of loessderived deposits in the semi-desert and desert fringe areas of Israel. Z Geomorphol 20:91-105

Yair A (1990) The role of topography and surface cover upon soil formation along hillslopes in arid climates. Geomorphology 3:287-299

Yair A (1992) The control of headwater area on channel runoff in a small arid watershed. In: Parsons AJ, Abrahams AD (eds) Overland flow: hydraulics and erosion mechanics. UCL Press, London, pp 53-68

Yair A (1994) The ambiguous impact of climate change at a desert fringe: Northern Negev, Israel, A.C. In: Millington AC, Pye K (eds) Environmental change in drylands: biogeographical and geomorphological perspectives. Wiley, Chichester, pp 199-227

Yair A, Danin A (1980) Spatial variations in vegetation as related to the soil moisture regime over an arid limestone hillside, Northern Negev Israel. Oecologia 47:83-88

Yair A, Raz-Yassif N (2004) Hydrological processes in a small arid catchment: scale effects of rainfall and slope length. Geomorpholohgy 61:155-169

Yair A, Shachak M (1982) A case study of energy water and soil flow chains in an arid ecosystem. Oecologia 54:389-397

Yao S-H, Zhang B, Hu F (2010) Biophysical controls over mineralization and sequestration of amended organic carbon in soil: effects of intensity and frequency of drying and wetting cycles. World Congress of Soil Science: Soil solutions for a changing world. Brisbane, Australia

Yoo K, Amundson R, Heimsath AM, Dietrich WE (2006) Spatial patterns of soil organic carbon on hillslopes: integrating geomorphic processes and the biological C cycle. Geoderma 130:47-65

Zaady E, Groffman P, Shachak M (1996) Litter as a regulator of N and C dynamics in macrophytic patches in Negev Desert soils. Soil Biol Biochem 28:39-46

Zak JC, Willig MR, Moorhead DL, Wildman HG (1994) Functional diversity of microbial communities: a quantitative approach. Soil Biol Biochem 26:1101-1108

Zhou ZY, Li FR, Chen SK, Zhang HR, Li G (2011) Dynamics of vegetation and soil carbon and nitrogen accumulation over 26 years under controlled grazing in a desert shrubland. Plant Soil 341:257-268

Zohary M (1962) Plant life in Palestine, Israel and Jordan. The Roland Press Co., New York, p 262 